\title{
Front Matter: Volume 11562
}

, "Front Matter: Volume 11562," Proc. SPIE 11562, AOPC 2020: Advanced Laser Technology and Application, 1156201 (5 November 2020); doi: $10.1117 / 12.2586148$

SPIE Event: Applied Optics and Photonics China (AOPC 2020), 2020, Beijing, China 


\title{
AOPC 2020: Advanced Laser Technology and Application
}

\author{
Zhiyi Wei \\ Jing Ma \\ Wei Shi \\ Xuechun Lin \\ Cunlin Zhang \\ Yongzhen Huang \\ Jian Zhang \\ Yangjian Cai \\ Pu Zhou \\ Wenxue Li \\ Zhaojun Liu \\ Editors
}

30 November - 2 December 2020

Beijing, China

Sponsored by

Chinese Society for Optical Engineering (CSOE) (China)

Technical Sponsor

SPIE

Organized by

Chinese Society for Optical Engineering (CSOE) (China) - Academy of Opto-Electronics of

Electronics Technology of China (China) - Science and Technology on Low-light-level Night Vision Laboratory (China) - Science and Technology on Electro-Optical Information Security Control (China)

Published by

SPIE

\section{Volume 11562}


The papers in this volume were part of the technical conference cited on the cover and title page. Papers were selected and subject to review by the editors and conference program committee. Some conference presentations may not be available for publication. Additional papers and presentation recordings may be available online in the SPIE Digital Library at SPIEDigitalLibrary.org.

The papers reflect the work and thoughts of the authors and are published herein as submitted. The publisher is not responsible for the validity of the information or for any outcomes resulting from reliance thereon.

Please use the following format to cite material from these proceedings:

Author(s), "Title of Paper," in AOPC 2020: Advanced Laser Technology and Application, edited by Zhiyi Wei, Jing Ma, Wei Shi, Xuechun Lin, Cunlin Zhang, Yongzhen Huang, Jian Zhang, Yangjian Cai, Pu Zhou, Wenxue Li, Zhaojun Liu, Proceedings of SPIE Vol. 11562 (SPIE, Bellingham, WA, 2020) Sevendigit Article CID Number.

ISSN: 0277-786X

ISSN: 1996-756X (electronic)

ISBN: 9781510639454

ISBN: 9781510639461 (electronic)

Published by

SPIE

P.O. Box 10, Bellingham, Washington 98227-0010 USA

Telephone +1 3606763290 (Pacific Time) · Fax +1 3606471445

SPIE.org

Copyright (c) 2020, Society of Photo-Optical Instrumentation Engineers.

Copying of material in this book for internal or personal use, or for the internal or personal use of specific clients, beyond the fair use provisions granted by the U.S. Copyright Law is authorized by SPIE subject to payment of copying fees. The Transactional Reporting Service base fee for this volume is $\$ 21.00$ per article (or portion thereof), which should be paid directly to the Copyright Clearance Center (CCC), 222 Rosewood Drive, Danvers, MA 01923. Payment may also be made electronically through CCC Online at copyright.com. Other copying for republication, resale, advertising or promotion, or any form of systematic or multiple reproduction of any material in this book is prohibited except with permission in writing from the publisher. The CCC fee code is 0277 $786 \mathrm{X} / 20 / \$ 21.00$.

Printed in the United States of America by Curran Associates, Inc., under license from SPIE.

Publication of record for individual papers is online in the SPIE Digital Library.

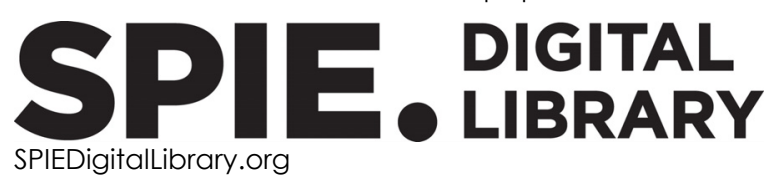

Paper Numbering: Proceedings of SPIE follow an e-First publication model. A unique citation identifier (CID) number is assigned to each article at the time of publication. Utilization of CIDs allows articles to be fully citable as soon as they are published online, and connects the same identifier to all online and print versions of the publication. SPIE uses a seven-digit CID article numbering system structured as follows:

- The first five digits correspond to the SPIE volume number.

- The last two digits indicate publication order within the volume using a Base 36 numbering system employing both numerals and letters. These two-number sets start with 00, 01, 02, 03, 04, 05, 06, 07, 08, 09, OA, OB ... 0Z, followed by 10-1Z, 20-2Z, etc. The CID Number appears on each page of the manuscript. 


\section{Contents}

ADVANCED LASER TECHNOLOGY AND APPLICATION

$1156202 \quad$ Study on in-chip phase locked high brightness bottom emitting Talbot-VCSELs array [1 1562-1]

$1156203 \quad$ A high energy end pumped Q-switched all solid state laser [1 1562-2]

1156204 Passively Q-switching in the direct AIGaAs LD pumped Tm/Ho composite laser [11562-4]

1156205 A method for measuring the width of a focused laser beam in reflection [1 1562-5]

1156206 A high-power MOPA all-fiber picosecond laser based on a novel two-dimensional perovskite saturable absorber mode-locked [11562-6]

1156207 Segmentation of street trees from MLS point clouds by dimensional feature analysis and improved FCM algorithm [1 1562-7]

1156208 Physical fundamentals electronic control over generation properties of all-fibre mode-locked lasers [1 1562-9]

1156209 Research on the influence of fog on laser transmission based on Monte Carlo method [11562-10]

11562 OA High repetition rate, high pulse energy fiber-solid hybrid picosecond regenerative amplifier system [11562-11]

$11562 \mathrm{OB} \quad$ Electrically controlled tunable optical parametric oscillator (3.0-6.7 $\mu \mathrm{m}) \mathrm{based}_{\text {on }} \mathrm{BaGa}_{4} \mathrm{Se}_{7}$ crystal pumped by a Q-switch Nd:YAG laser [11562-12]

11562 OC Research on terahertz photoconductive antenna and its array [11562-13]

11562 OD Control of self-excited oscillation by $\mathrm{Nd}^{3+}$ ion doping concentration for end-pumped NdYAG Q-switched laser [11562-14]

11562 OE Characterization of the lacquerware from the Palace Museum by THz reflectometric imaging [1 1562-15]

11562 OF Improvements and applications for laser system simulation software: EasyLaser [11562-16]

$115620 \mathrm{O}$ High-energy hundred-picosecond hybrid fiber and solid-state laser amplifier system for laserinduced damage application [1 1562-17]

$11562 \mathrm{OH} \quad$ Influence of cavity length on modes selection of dynamic stable zone [11562-18] 
$11562 \mathrm{Ol} \quad$ Performance prediction of single-longitudinal-mode operation in Pr:YLF laser under pre-lase technology [11562-19]

$115620 \mathrm{~J} \quad$ Temperature rise and damage morphology of APD in external capacitor circuit irradiated by millisecond pulse laser with different pulse widths [1 1562-20]

11562 OK Theoretical and experimental study of the dual-wavelength alternately Q-switched Nd:YAG laser [1 1562-22]

$11562 \mathrm{OL} \quad$ Processing of Janus micropillars based on femtosecond laser and vacuum evaporation [1 1562-23]

11562 OM The influence of cat's eye effect on CEMRR FSO gain under defocus oblique incidence [1 1562-24]

$11562 \mathrm{ON} \quad$ Laser cleaning of adhesive on the ceramics [11562-25]

1156200 Study on the transmission characteristics of laser through inhomogeneous cirrus clouds [1 1562-26]

11562 OP Ho:YAP laser intra-cavity pumped by a diode-pumped Tm:YAP laser [1 1562-27]

$115620 Q \quad$ A one-dimensional beam shaping system design for semiconductor laser [11562-29]

11562 OR Feature of spaceborne laser communication telescope isolation [11562-31]

11562 OS The study of body wave generated by scanning continuous laser [1 1562-32]

11562 OT Measurement of ultrafast laser damage threshold on optical materials [1 1562-34]

11562 OU Dissipative soliton resonances in normal and anomalous dispersion regimes by Using a CFBG for dispersion management [11562-35]

11562 OV Label-free characterization of cancerous ovarian tissues with continuous wave terahertz spectroscopy [11562-36]

11562 OW Simulation design of laser diode array side-pumped polygonal Nd:YAG thin-disk laser [1 1562-38]

11562 OX Additive manufacturing of copper alloy and its application in Munroe effects [11562-40]

11562 OY Coherently combining of fiber lasers based on two-stage phase control [1 1562-42]

11562 OZ Rectangular burst-mode Yb-doped fiber laser with MHz inter-repetition rate [1 1562-45]

$1156210 \quad$ Lateral mode tailoring in broad area diode lasers based on laterally coupled passive waveguide [11562-46] 
$1156211 \quad$ Laser cutting of fiber-reinforced plastic laminate and its honeycomb sandwich structure [11562-47]

1156212 Studies on automatic extraction of precise 3D laser measurement data in specific section of subway tunnel [1 1562-49]

1156213 Mode control on all-fiberized Raman fiber amplifier based on acoustically-induced fiber grating [1 1562-50]

1156214 Capacity of turbulent ocean link with point error and carrier of Bessel-Gaussian localized vortex wave [1 1562-52]

1156215 Research on laser-induced oxidation assisted processing technology of high volume fraction $\mathrm{SiC}_{\mathrm{p}} / \mathrm{Al}$ composites [11562-57]

1156216 Study on the graphite smoke echo characteristics of pulsed laser fuze [11562-59]

$1156217 \quad$ Vector beam splitting system [11562-60]

$1156218 \quad$ Mode-solved bending loss measurement for large-mode-area fiber based on spatial and spectral resolution imaging [11562-65]

1156219 Transducer design of acousto-optic modulators [11562-66]

$115621 \mathrm{~A} \quad$ A compact radial and azimuthal polarization purity analyzer [11562-67]

11562 1B Experimental analysis of the influence of Fresnel reflection on the phase noise in microwave photonic links [1 1562-68]

$115621 \mathrm{C} \quad$ High power Al-free CW 808nm laser diode bar [1 1562-70]

11562 1D Cutting the closed curve shape inside glass with laser induced thermal-crack propagation [11562-71]

$115621 \mathrm{E}$ The influence of APD space radiation damage degradation on the laser communication system BER [1 1562-72]

11562 1F Statistics and analysis of foreign military medium and heavy UAV accidents [11562-73] 
Proc. of SPIE Vol. 11562 1156201-6

Downloaded From: https://www.spiedigitallibrary.org/conference-proceedings-of-spie on 26 Apr 2023
Terms of Use: https://www.spiedigitallibrary.org/terms-of-use 